The Politics of Immigration in France, Britain, and the United States 


\section{Perspectives in Comparative Politics}

Published by Palgrave Macmillan

The Struggle against Corruption: A Comparative Study

Edited by Roberta Ann Johnson

Women, Democracy, and Globalization in North America: A Comparative Study

By Jane Bayes, Patricia Begne, Laura Gonzalez, Lois Harder, Mary Hawkesworth, and Laura Macdonald

Politics and Ethnicity: A Comparative Study

By Joseph Rudolph

Social Movements in Politics, Second Edition

By Cyrus Ernesto Zirakzadeh

The Politics of Immigration in France, Britain, and the United States: A Comparative Study By Martin A. Schain 


\title{
The Politics of Immigration in France, Britain, and the United States
}

\section{A Comparative Study}

\author{
Martin A. Schain
}




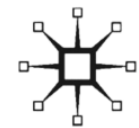

THE POLITICS OF IMMIGRATION IN FRANCE, BRITAIN, AND THE UNITED STATES

Copyright (C) Martin A. Schain, 2008.

Softcover reprint of the hardcover 1st edition 2008 978-1-4039-6215-7

All rights reserved.

First published in 2008 by

PALGRAVE MACMILLAN ${ }^{\circledR}$

in the United States-a division of St. Martin's Press LLC,

175 Fifth Avenue, New York, NY 10010.

Where this book is distributed in the UK, Europe and the rest of the world, this is by Palgrave Macmillan, a division of Macmillan Publishers Limited, registered in England, company number 785998, of Houndmills, Basingstoke, Hampshire RG21 6XS.

Palgrave Macmillan is the global academic imprint of the above companies and has companies and representatives throughout the world.

Palgrave ${ }^{\circledR}$ and Macmillan ${ }^{\circledR}$ are registered trademarks in the United States, the United Kingdom, Europe and other countries.

ISBN 978-1-4039-6216-4 ISBN 978-0-230-61666-0 (eBook)

DOI 10.1057/9780230616660

Library of Congress Cataloging-in-Publication Data

Schain, Martin, 1940-

The politics of immigration in France, Britain, and the United States : a comparative study / Martin Schain.

p. cm.-(Perspectives in comparative politics)

Includes bibliographical references and index.

1. France-Emigration and immigration-Government policy.

2. France-Emigration and immigration-Political aspects.

3. Great Britain-Emigration and immigration-Government policy.

4. Great Britain-Emigration and immigration-Political aspects.

5. United States-Emigration and immigration-Government policy.

6. United States-Emigration and immigration-Political aspects.

I. Title.

JV7933.S34 2008

$325-\mathrm{dc} 22$

2008012345

A catalogue record of the book is available from the British Library.

Design by Newgen Imaging Systems (P) Ltd., Chennai, India.

First edition: October 2008

$\begin{array}{llllllllll}10 & 9 & 8 & 7 & 6 & 5 & 4 & 3 & 2 & 1\end{array}$

Transferred to Digital Printing 2008 
For Wendy 



\section{O N T E N T S}

List of Figures and Tables ix

Series Editor's Foreword xiii

Preface and Acknowledgments $\quad$ xv

One Introduction: The Politics of Immigration 1

Two Development of French Immigration Policy 37

Three Understanding French Immigration Policy 63

Four Politics of Immigration in France 89

Five Development of British Immigration Policy 119

Six Understanding British Immigration Policy 141

Seven Politics of Immigration in Britain 161

Eight Development of U.S. Immigration Policy 181

Nine Understanding U.S. Immigration Policy 207

Ten Politics of Immigration in the United States 237

$\begin{array}{ll}\text { Eleven Conclusion } & 275\end{array}$

Notes $\quad 285$

Bibliography 313

Index 323 



\section{I S T O F F I G U R E S}

\section{A N D T A B L E S}

\section{Figures}

5.1 Migration flows into the United Kingdom

\section{Tables}

1.1 Immigration and immigrant populations in France, Britain, and the United States, 1992-2001

1.2 Extent of support for restricting immigration, percentage by age cohort, 2004

1.3 Unemployment rates for immigrants and natives in 2003-2004

1.4 Educational attainment of immigrants populations, 2004

1.5 Unemployment rates of foreign-born populations, by level of education attainment, 2003-2004

1.6 Political integration of immigrant populations

1.7 Attitudes toward immigrants and Muslims

1.8 Muslims in Europe: Attitudes toward identity, fellow citizens, and modernity

1.9 Policy choice for integration of Islam of Muslim elites, by country of residence

2.1 Foreigners residing in France, 1851-2005 40

2.2 French immigration legislation 41

2.3 Percentage of foreigners in specific industries 44

2.4 The changing pattern of immigrant populations resident in France, 1975-1999 (thousands, unless indicated) 
2.5 The flow of foreigners into France, 1974-1999 50

3.1 Immigrants entering France under family unification 67

3.2 France: Stock and inflow of North African population 68

3.3 Asylum-seekers and recognition rates, 1981-2004 69

3.4 Article 22 expulsions ("Reconduites à la frontière") 71

3.5 Sympathy/antipathy index for immigrant groups, 1966-1993

3.6 Integration index for immigrant groups, 1951-1988 74

3.7 Foreigners in France 76

4.1 The motivations of voters, 1984-1997 (percentage of party voters voting for these reasons)

4.2 Percentage of respondents who claim there are "too many Arabs in France"

4.3 Circumscriptions in France (métro) with 10 percent + population immigrant (1999), by the party of the deputy

5.1 Legislation on immigration and citizenship in Britain

5.2 Immigration and emigration to and from the United Kingdom since 1890

5.3 UK Population born abroad, by origin and percentage of population

5.4 Changing categories of British citizens and aliens, 1948-1981

5.5 Stock of population born abroad

6.1 Net migration in and out of the United Kingdom (thousands of people)

6.2 Asylum-seekers and recognition rates: 1997-2004 146

6.3 Opposition to immigration in Britain 148

6.4 Attitudes toward immigrants in Britain

7.1 MPs attitudes on immigration and repatriation in 1969 (percentage)

175

7.2 British constituencies with 10 percent or more non-white population, by political representation

8.1 Unified party-control of government institutions in the United States, 1947-2007

8.2 U.S. legislation on immigration and citizenship

8.3 Importance of immigration in the United States 186

8.4 U.S. immigration and rates of immigration, 1840-1920 188

9.1 Changing immigration patterns after WWII 211

9.2 U.S. immigration by classification of admission 214

9.3 U.S. immigration by region 215

9.4 Millions of unauthorized immigrants living in the United States 218

9.5 Asylum applications and acceptance in the United States 219 
9.6 Opposition to immigration in the United States

9.7 Immigration and public opinion in the United States, 1993-2005

9.8 Do you think that the number of immigrants now entering the United States from each of the following areas is too many, too few, or about the right amount?

9.9 In your view, does the increasing diversity in the United States that is created by immigrants mostly improve American culture or mostly threaten American culture?

9.10 U.S. attitudes toward immigrants and concentrations of immigrant populations

9.11 The political priority of immigration issue 227

9.12 Hispanic elected office-holders in the United States, 1984-2005

10.1 "Know Nothing" representation in the U.S. Congress, 1855-1859

10.2 The changing restrictionist majority in the House of Representative

10.3 Votes in the House of Representatives to override the veto of President Truman of the McCarran-Walter Act in 11 Southern states, 8 states in the Northeast, and California in 1952

10.4 The isolation of the restrictionist minority

10.5 U.S. Congressional Districts 10 percent + born outside of the United States (2000) after congressional elections of 1998 



\section{SER I E S E D I T O R'S F O R E W O R D}

All books in this series, Perspectives in Comparative Politics, are designed to be scholarly, topic-oriented studies of a particular problem, fully accessible to undergraduate students who are approaching the subject for the first time as political scientists, as well as replete with new information and new insights that will intrigue graduate students and professors who have prior knowledge of the subject. Each begins with an introductory chapter, covering the relevant literature and laying out the problem, and ends with a concluding chapter, summarizing what has been learned about the problem at hand in the three or more nations covered, and elucidating the important comparative lessons learned.

Despite adherence to the overall design of the series, every book has its own very special character. The topics, the nations chosen as case studies, and, above all, the author, ensure this rich variety. Professors adopting different books in the series for classroom use will always find not only the comforting familiarity of the expected design, but also the surprise and delight of engaging new ideas presented by authors working from long experience, deep understanding, and passion. The authors in this series care deeply about their topics, and it shows. They maintain impeccable loyalty to the norms of objective scholarship, and at the same time demonstrate how well such scholarship can serve an argument for change. Students learn not only about the topic and the cases, but they also learn, by the example set within the book itself, important lessons about the comparative method and the norms of scholarship.

THE POLITICS OF IMMIGRATION IN FRANCE, BRITAIN, AND THE UNITED STATES: A COMPARATIVE ANALYSIS, by Martin A. Schain of New York University, nicely demonstrates the capacity of its author to provide an absolute wealth of essential information, offer instruction by example in the comparative method, and at the same time make strongly original and insightful comments, well documented, on the topic. This book begins with an overview of the problems of immigration policy and the politics of immigration as they have presented themselves in the world - and in the political science literature-and then offers three chapters on France, three on Britain, and three on the United States, before concluding with a chapter that points out the strongest differences and similarities found among the three as they grapple with this 
most timely-and sometimes most vexing-problem: how to balance the complex and often contradictory needs that emerge and compete for political and governmental solution when large numbers of others wish to join existing citizenries on territories they consider to be unalienably their own.

The thoroughness of Professor Schain's research, presented in nearly 60 tables and figures as well as in clear and persuasive text, has led to numerous new discoveries and new understandings. He finds, for example, that Muslim immigrants in France "are, by far, the most integrative in their orientation, and the least conflicted between their Muslim and national identities." He brings out the multitudinous ways in which sheer racism has infected the policymaking process at times in the histories of all three nations. He shows that both prongs of the commonly held belief that the British have been strongly in favor of "zero-immigration" and good at enforcing such a policy is not supported by the facts. He has given us, overall, a strikingly well-documented study, one that summarizes, compares, contrasts, and challenges. It is both an important contribution to the literature, and a highly competent text.

I am very pleased indeed to have this book, THE POLITICS OF IMMIGRATION IN FRANCE, BRITAIN, AND THE UNITED STATES: A COMPARATIVE ANALYSIS, join the Palgrave series Perspectives in Comparative Politics. 


\section{P R E F A C E A N D}

\section{A C K N O W L E D G M E N T S}

This book began with a few impassioned comments from a group of Communist mayors, whom I was interviewing for a study of Communist local government more than 25 years ago. I was interested in how they were able to develop local policy, but they were far more determined to talk to me about immigrants and immigration. To my surprise, they were neither sympathetic with this new working class, nor were they particularly supportive, and their comments provoked me to investigate the reaction of the left to a growing immigrant population from outside of Europe.

During the years that followed my interest in the emerging politics of immigration brought me to France with some frequency, where I was welcomed by a community of scholars who helped shape my thinking about politics and immigration. I was invited to give presentations, to participate in colloquia, and to exchange ideas with a small, but growing group of scholars, who were beginning their own scholarly work in this area. Over the years this group has increased both in size and in visibility, as the study of immigration has become important among social scientists in Europe and in the United States.

I count myself lucky that some of the most talented and innovative scholars on both sides of the Atlantic decided to work in this area. This community of scholars has been engaged in a continuing conversation that has spanned generations, as well as the Atlantic. We have talked with one another, and been influenced by one another's work.

In France, I am particularly grateful to Jeanne and Daniel Singer, who welcomed me into their home on the Rue de Bièvre where countless numbers of scholars have gathered for many years. Sophie Body-Gendrot and I have written together, and my work on immigration policy has been deeply influenced by our continuing discussions year after year, both in Paris and New York. Catherine de Wenden shared with me both her own work and her perceptions into immigration policy, and Patrick Weil has been an unending source of ideas and insights. To Riva Kastoryano I owe a special debt for her insights and analysis of immigrant integration and Virginie Guiraudon has taught me a great deal about immigration policymaking 
at the EU level. I am also grateful to Ariane Chebel-d'Appolonia who invited me to be a visiting scholar at the Institut d'Etudes Poliques de Paris, and to Nancy Green, who invited me to share a seminar with her at the êcole des Hautes Etudes in 2003. Thanks to these invitations I was able to present many of the ideas in this book, and test them out with both of these fine scholars, as well as their colleagues.

Sciences-Po (The Institut d'Ëtudes Politiques de Paris) has been my university away from home since I was a graduate student, and has welcomed me back many times since. Pascal Perrineau, the director of the Centre d'Etude de la Vie Politique Française (CEVIPOF) has given me friendship, support, and space to work. Martine Papacostas created miracles to help me and my wife Wendy through the immigration bureaucracy during our two extended stays in France, a feat that I continue to admire. Our two stays in Paris were also enhanced by the many friends and colleagues who had little to do with my research and writing, and who helped to make Paris our second city. I am grateful for the friendship of Monica and Francis, Irene and Hugo, Michel and Elisabeth, Pierre and Marie-Hélène, Pascal and Gisèle, Alain and Sophie, Yvonne, and Michèle and Suguru.

In the United States, I was privileged to interact with a growing community of scholars whose work on immigration has been seminal for scholarship in comparative politics and international relations in this area. I was lucky enough to encounter Aristide Zolberg after he arrived at the New School. Soon after, we became co-directors of the New York Consortium for European Studies, and were able to organize a series of workshops that brought a new generation of immigration scholars to New York. Some debts never get paid back, only acknowledged. Ary's work in this area has had an enormous impact on my own thinking, and helped provide a comparative context for understanding the politics of immigration. I am also grateful for the work of other scholars with whom I have shared ideas, papers and dialogues. Jim Hollifield and I have been talking about comparative immigration questions since we first met twenty years ago. Jeannette Money strongly influenced my thinking about the importance of immigration in electoral politics, Miriam Feldblum my thinking on neo-nationalist change, and Gary Freeman my thinking more generally on immigration impact. I am very pleased that Richard Alba and Nancy Foner, two of the most creative scholars working on immigration in the United States, shared their work with me on immigrant political participation. Gallya Lahav has been a very special scholar for me. She was my graduate student, and is now a major scholar in her own right. More to the point, I am appreciative of her scholarly work that has given us original ways of understanding the relationship between public opinion and immigration. Finally, I am grateful to Christopher Mitchell, my friend and colleague in the Department of Politics at New York University, for his comments on the chapters on the United States. 
In Britain, this study has been influenced by Randall Hansen's analysis of the shift of British immigration policy in the 1960s. Erik Bleich's groundbreaking work on discrimination has helped define my understanding of the formulation of British policy on immigration; and Tariq Modood's work consistently challenges my ideas about multiculturalism and integration. Anthony Messina's recent book is one of the best books on the politics of migration in Western Europe, but I have relied a great deal on his equally impressive earlier work on race relations and British political parties.

There is relatively little work that deals with comparative immigration politics. Therefore, I am thankful for the pioneering work of Christian Joppke and Andrew Geddes that is cited in this volume. During my years as director of the Center for European Studies (now the Center for European and Mediterranean Studies) at New York University, dozens of visiting scholars working of the politics of immigration spent time in New York. I am particularly indebted for the feedback and interactions over many years to Ted Perlmutter, Leah Haus, Amy Elman, Jonathan Laurence, Marco Martiniello, Damir Skenderovic, Michael Minkenberg, Anand Menon, Willem Maas, and Elise Langan.

Kay Lawson, the editor of this series, has been a perfect editor. She has been patient, prodding, and encouraging. She is a friend and colleague whom I have known for many years, and, at the end of this process, we are still friends. I am grateful for her careful reading or this entire manuscript, and for her perceptive comments. Anthony Wahl, my editor at Palgrave has equally admirable virtues. For most of the past decade, we have worked on numerous projects together, including my own series for Palgrave. I am thankful for his keen sense of the possible, and for his support and encouragement of this book. I also want to thank Leah Ramirez, who has assisted me on many projects, for her careful work on the index of this book.

Finally, I am most grateful for the support of my family and especially my wife Wendy. Wendy has been a part of this project in many important ways. She has traveled with me, has been subjected to my endless discussions of this passionate subject, and has met friends and colleagues-many of whom have become her friends as well-who have been equally passionate. She has been my most challenging critic, and has taken the time to be my best editor as well. She has certainly made this a better book.

Of course, the usual disclaimers apply. Although the scholars and friends I have acknowledged have made this a better book, only I am responsible for what I have written. 